\title{
SUICIDE WITH MASSIVE DIGOXIN OVERDOSE \\ (A CASE REPORT)
}

\author{
K.A.S. Kodikara \\ Dept. of Forensic Medicine, Faculty of Medicine \\ University of Peradeniya, Sri Lanka
}

\section{Introduction}

Cardiovascular drugs are among the substances most often implicated in poisoning in the elderly ${ }^{1}$. Digoxin is a steroid glycoside which is widely used in the treatment of cardiac failure, atrial fibrillation, atrial flutter, and paroxysmal supraventricular tachycardia. Although digoxin intoxication is a common problem in clinical practice because it is therapeutically effective within a narrow dose range, massive intoxication with digoxin following a suicidal attempt is a rare event. This case report illustrates a massive digoxin overdose in a suicidal 51year-old man, in which measurement of serum digoxin concentration far exceeds the values so far reported in the literature.

\section{Case report}

A 51-year-old general practitioner was admitted to the hospital unconscious and was pronounced dead immediately. It was revealed that the deceased had threatened to commit suicide during a heated family argument just one hour before admission to the hospital. Apparently he had swallowed twenty, $0.25 \mathrm{mg}$ digoxin tablets that he had in his practice. The incident was witnessed by family members.

A medico legal autopsy was performed and the main findings included congestion of brain, lungs, and kidneys and a partially digested rice meal in the stomach. There were no identifiable tablets inside the stomach but dissolved tablet particles were seen. Myocardial and coronary artery diseases were excluded. The other organs were unremarkable. Blood, stomach contents and liver were analysed for digoxin levels.

This analysis revealed digoxin concentrations of $7 \mu \mathrm{g} / \mathrm{ml}, 1 \mu \mathrm{g} / \mathrm{g}$ and $137 \mu \mathrm{g} / \mathrm{g}$ in blood, liver and stomach contents respectively. These results were verified by repeated analysis.

\section{Discussion}

The effects of cardiac glycosides are direct stimulation of the myocardium, increased myocardial excitability and automaticity leading to cardiac arrhythmias, depression of conducting tissue and increased vagal activity. Cardiac glycosides inhibit the enzyme sodium potassium ATPase. Inhibition of this enzyme by cardiac glycosides is dose related and at high concentrations interference with sodium, calcium and potassium transport is probably responsible for digoxin induced arrhthymias. Anorexia, nausea, vomiting, supraventricular tachyarrhythmia and atrioventricular block are suggestive of digoxin toxicity. The elderly experience adverse effects of digoxin more readily. This results largely from a decline in renal clearance with age. 
After ingestion, digoxin is absorbed quickly and peak plasma concentration of digoxin is reached in 30-60 minutes. It will begin to have an effect on the heart within 1-2 hours following oral administration. Digoxin distributes widely throughout the body specially in heart, skeletal muscles, liver and kidneys.

Digoxin has a narrow therapeutic range. The mean therapeutic serum concentration of digoxin ranges from 0.5 to $2 \mathrm{ng} / \mathrm{ml}$. Digoxin toxicity starts at a serum level of $2.0 \mathrm{ng} / \mathrm{ml}^{2}{ }^{2}$ It is common with up to $20 \%$ of hospitalised patients receiving digoxin showing some evidence of toxicity. ${ }^{3}$ A significant increase in mortality was correlated with an increasing serum digoxin level up to $50 \%$ at a level of $6.0 \mathrm{ng} / \mathrm{ml}$ and more. ${ }^{4}$

Suicide with massive digoxin overdose is a rare event. In 1971 Smith and Willerson reported a postmortem serum digoxin level of $42 \mathrm{ng} / \mathrm{ml}$ in a case of suicidal digoxin intoxication. $^{5}$ Likewise in 1973 Hobson and Zettner reported 25ng/ml ${ }^{6}$ in 1975 DiMaio et al reported 38.6 $\mathrm{ng} / \mathrm{ml}{ }^{7}$, and in 1994, Dunn et al reported $169 \mathrm{ng} / \mathrm{ml}^{8}{ }^{8}$ In this case, the serum digoxin level is extraordinarily high. This is likely due to ingestion of large number of digoxin tablets.

Acute massive digoxin overdose in this patient would have caused life threatening arrhythmias mainly atrioventricular conduction disturbances which led to immediate death. Also refractory hypokalaemia can contribute to the cause of death in digoxin poisoning. 9 .

The cause of death was concluded as digoxin intoxication. The history of this case and autopsy findings led to assume a suicidal mode of death. It appears that the deceased made use of his professional knowledge to choose a drug which is not usually used in cases of attempted suicide. Thus, the first ever case of suicide with massive digoxin intoxication is reported in Sri Lanka. Blood digoxin concentration in this case far exceeds the values so far reported in the literature and indicates ingestion of extraordinary amounts of digoxin.

\section{References}

1. Klein-Schwartz W, Oderda GM. Poisoning in the elderly. Epidemiological, clinical and management considerations. Drugs Ageing 1991; 1: 67-89.

2. Smith TW, Butler VP, Harber E. Determination of therapeutic and toxic serum digoxin concentrations by radioimmunoassay. New England J Med 1969; 281: 1212-1216.

3. Smith TW, Harber E. The clinical value of serum digitalis glycoside concentrations in the evaluation of drug toxicity. Ann NY Acad Sci 1971; 179: 322-376.

4. Ordog GJ, Benaron S, Bhasin V, Wasserberger $\mathrm{J}$, and Balasubramanium $\mathrm{S}$. Serum digoxin levels and mortality in 5100 patients. Ann Emerg Med 1987; 16 (1): 3239.

5. Smith TW, Willerson JT. Suicidal and accidental digoxin ingestion. Circulation 1971; 44: 29-36.

6. Hobson JD, Zettner A. Digoxin serum halflife following suicidal digoxin poisoning. JAMA 1973; 223: 147-149.

7. DiMaio VJM, Garriot JC, Putnam R. Digoxin concentrations in post-mortem specimens after overdose and therapeutic use. J Forensic Sci 1975; 20(2): 340-347.

8. Dunn WA, Lockrey LA, McCain MW, Siek TJ. A report of a suicide involving digoxin and doxepin. J Anal Toxicol 1994; 18: 122123.

9. Pick A, Igarashi M. Mechanism, differential diagnosis, and clinical significance of digitalis-induced arrhythmias. In: Surawicz B, Fisch C, editors. Digitalis. New York: Grune and Stratton Inc., 1969: 148. 